\title{
Heidegger's Reflection on Aletheia: Merely a Terminological Shift?
}

GARY STEINER

Yale University

In "The End of Philosophy and the Task of Thinking," Heidegger discusses the need to move beyond prior philosophical thinking to the determination of the proper matter of thinking. In first encountering this idea, which has the form of an injunction to think the philosophical tradition in a way which enables us to "overcome" that tradition, one may be seized with the inclination to lodge the kind of thoroughgoing critique of the tradition which puts one in position to bury and forget it as if it were a bad dream. Some self-styled "Heideggerians" employ this tack in an attempt to exponge from philosophy the notions of subjectivity and presence, as if these notions were nothing more than an elaborate and painfully embarrassing mistake which should simply be forgotten; then the "task" of philosophy, if there still is one, is to articulate a realm of "non-metaphysical" discourse in which anything goes as long as it does not involve the dirty words "subjectivity" and "presence." But at best such a posture bears only a superficial resemblance to Heldegger's position. While Heidegger does seek to "overcome" the tradition and its fundamental presuppositions about Being, he is not enjoining us to jettison the tradition but rather to appropriate it productively, to transform its concepts in the way in which concepts become aufgehoben in Hegelian dialectic. It is in this spirit that Heidegger devoted his life to the study of the history of philosophy. (Here we should bear in mind that Heidegger considered philosophy to be a peculiarly occidental pursuit.) And it is in this spirit that we must interpret Heidegger's reflection on aletheia in "The End of Philosophy and the Task of Thinking:" if we try to think unconcealment in isolation from the traditional understanding of Being as presence, and if we try to understand our own being in isolation from traditional concepts of human being which culminate in the modern notion of Subjectivity, then we fail to think the matter of philosophy authentically and end up engaging in meaningless word-play. It is true that on Heidegger's account the tradition has gone astray, but it is the very crux of his account that we are destined to do so. And perhaps the most conspicuous example of this er- 
rancy is Heidegger's own attempt in Being and Time to equate aletheia and truth. In "The End of Philosophy and the Task of Thinking," Heidegger says that "[t]o raise the question of aletheia, of unconcealment as such, is not the same as raising the question of truth. For this reason, it was inadequate and misleading to call aletheia in the sense of opening, truth." I If we decide that the equating of aletheia and truth amounts to no more than a terminological blunder on Heidegger's part, then we ourselves are making a serious mistake. If we are to understand the shift in Heidegger's thinking about aletheia in Being and Time, we must productively appropriate that earlier thinking rather than turn our backs on it. It is for this reason that the bulk of the following discussion is devoted to an examination of the position which Heidegger at least seems to abandon in "The End of Philosophy and the Task of Thinking."

This discussion is divided into three parts. The first considers some of Heidegger's remarks concerning truth in Being and Time, and relies on several of Heidegger's Marburg lectures as a way of filling out Heidegger's position. The second part sets up Heidegger's claim in "Plato's Doctrine of Truth" that the Platonic corpus reflects a shift in the essence of truth from unconcealedness to correctness or correspondence. And the third part examines Heidegger's claim in "The End of Philosophy and the Task of Thinking" that he was wrong to say that the essence of truth underwent a transformation in the early Greek world, and the accompanying claim that it was a mistake to equate aletheia as unconcealedness with truth in the first place. While at first glance this shift in Heidegger's position might seem to be a mere redefinition of terms, I want to say that it forces us to rethink the very notion of clearing in Heidegger's writings. In Being and Time Heidegger conceives of the clearing (Lichtung) as a finite human one; on this view, the disclosedness of Being to Dasein is "phenomenological truth," 2 and the discoveredness of beings is also a kind of truth." But in his later writings the term "truth" is reserved for the traditional notion of correctness, and Dasein's disclosedness and discursive articulation of beings are no longer considered to be "true" but rather ground the possibility of the truth and falsity of assertions or representations." At the same time, the clearing is no longer conceived as one which can be so interpreted that it reveals to us the meaning of Dasein's Being and the meaning of Being generally: rather, the shift in Heidegger's conception of truth brings with it a conception of the clearing which emphasizes the mysterious, non-totalizable, nonrepresentable character of Being; that shift signals an attempt to "overcome" metaphysics, to subordinate the "calculative thinking" characteristic of the technolog- 
ical age to the "meditative thinking" which seeks to be open to the mystery of Being."

\section{Heidegger's Concept of Truth in "Being and Time"}

Erom the start Heidegger's discussion of truth is influenced by Aristotle; this is already apparent in paragraph 7 (b) of Being and Time when Heidegger discusses the meaning of the term logos. Heidegger says that "the basic meaning of logos is "discourse" "and adds that "Illogos does not mean judgement", and it certainly does not mean this primarily--if one understands by 'judgement' a way of 'binding' something with something else, or the 'taking of a stand' (whether by acceptance or by rejection)" (BT $55 \mathrm{ff}$ ). Here Heidegger is thinking of Aristotle's view that assertion or judgement (logos apophantikos) is a branch of the broader logos semantikos. That for Aristotle discourse is in its broadest characterization semantic, means that discourse makes beings manifest or lets them be seen. "The function of discourse is deloun--the making manifest of beings." Discourse makes manifest what the discourse is about, and makes it manifest to those engaging in the discourse (BT 56). Apophantic logos is a special kind of making manifest, namely the kind which occurs in informing people or in pointing things out. When Heidegger discusses apophansis in paragraph 33 of Being and Time, he calls it a predicative pointing out which informs. Here pointing out means letting a being be seen from itself, and this pointing out has a predicative structure. The defining which occurs in predication does not first discover that which shows itself as such, but limits seeing to this self-showing something in order to make "that which is manifest explicitly manifest in its definite character" (BT 197). And the assertion informs insofar as it shares with another the being which has been thus pointed out in its determinateness. This determination of a being in assertion takes the form of a "dimming down" (abbleden. Entblendung) to, e.g.. "that hammer there;" the positing of a subject, a predicate; and the togetherness of the two is apophansis (BT 197).

Aristotle says that it is the synthetic structure of assertion which makes it possible for an assertion to be true or false. Unlike aisthesis (sense perception) and noesis (mental perception of simple natures). which can either disclose (present) or fail to do so, the articulation of concepts conditions the possibility of error for Aristotle. Only at the level of dianoesis or discursive thought does the possibility arise that things will be combined in thought which are not combined in reality. And insofar as words are for Aristotle symbols of mental experience ("Spoken words are the symbols of mental experience and written words are the symbols of spoken words") the truth of assertions is 
for Aristotle doubly founded: such truth, which pertains to the predicative use of language, presupposes both perception of essences or simple objects of thought and the presence of discursive thought.

Here it will be helpful to summarize Aristotle's notion of truth briefly. Aisthesis and noesig are always true; they cannot be false, but at most can fail to occur. The possibility of falsity depends on synthesis,. Which is found in discursive thinking (dianoesis) and in a particular use of language (logos) which represents that thinking, namely in assertion (logos apophantikos).

Against the background of Aristotle's notion of truth as logos apophantikos, Heidegger weaves the notion of assertion into his account of human Dasein. While for Aristotle the synthesis-structure of assertion makes it possible for assertions to be false as well as true, for Heidegger (and implicitly for Aristotle) the synthetic structure of assertion is grounded in the function of assertion as letting-be-seen-bypointing-out (BT 56). More generally, the possibility of assertion being true or false is grounded for Heidegger in the function of discourse as letting things be seen or as making things manifest. It is this move which is key for understanding Heidegger's appropriation of Aristotle.

Heidegger's departure from Aristotle can best be seen in the section on logos in paragraph 7 of Being and Time. There Heidegger suggests that the basic meaning of truth in the sense of aletheia is not correspondence but rather letting be seen (Sehenlassen) or discovering (Entdecken) (BT 56ff). For Heidegger, and according to him for the philosophers to whom he refers somewhat ambiguously as "the Greeks," logos is not the primary locus of truth. But while Heidegger has argued that the primary locus of truth for Aristotle is the complex of aisthesis and noesis. Heidegger's own move is quite different. Because on Heidegger's account bare staring is the most derivative kind of experience, we have to expect his account of letting things be seen to be radically different than Aristotle's (BT 189f). In fact Heidegger turns Aristotle's ontology on its head. While Heidegger retains Aristotle's insight that the truth of assertions must be grounded in a more primordial sense of truth, he appeals not to any variety of eidetic intuition but rather to the disclosedness of Dasein and his own notion of Dasein's discursive or interpretive activity. The notion that meaningful existence could begin with bare perceptual staring, whether this staring be sensory or eidetic, is anathema to Heidegger.

On Heidegger's view assertion is not only a mode of interpretation but is a derivative (abkünftiger) mode. In order to understand Heidegger's notion of assertion, we must thus understand his notion of interpretation 
generally. Heidegger calls interpretation "the working out of possibilities projected in understanding" (BT 189). These possibilities constitute, roughly speaking, a relational space or world in which Dasein always already finds itself. Dasein exists as thrown into a world of concern, and understands itself in terins of this space of possibilities. That Dasein is essentially interpretation means that Dasein is constantly working out the possibilities into which it has been thrown. In Being and Time this means that Dasein is the being which discovers: "That 'circumspection discovers' means that the 'world' which has already been understood comes to be interpreted" (BT 189). At the most fundamental level of interpretation, Dasein does not thematically grasp the possibilities onto which it projects; rather, at the level of everyday circumspection those possibilities are transparent. It is only at the level of assertion that Dasein's possibilities become explicit or thematic.

The distinction between interpretation generally and apophantic interpretation is best understood in terms of the 'as'-structure. The 'as' is a characteristic of all interpretation (BT 192) but has a somewhat different nature at different levels of interpretation. In our everyday dealings with things of use we are in some sense constantly "uncovering" or "discovering" those things. But in so discovering things of use we are not discovering them in the way in which, say, science discovers them; rather, we are oriented on what role the thing may play in the project at hand. At this level, things are for us "ready-to-hand": this means that things show themselves in a complex of reference relations with other things of use. (What I am referring to here as "things of use" are called variously "equipment" or "artifacts" by different translators of Heidegger.) This complex of reference relations is for Heidegger the structure of the world, and this mode of dealing with things is considered by him to be "more primordial" than the mode of assertion precisely because at this level things are just what we can do with them. Heidegger describes this being in terms of the "in order to": at the level of readinessto-hand, the hammer is not an object with determinate physical properties, but rather is in order to hammer nails, and nails are in order to hold boards together. and so forth. At the level of readiness-to-hand a hammer cannot be understood except in its relation to nails, boards, and the like. (This is what Heidegger means when he claims that there can be no such thing as an item of equipment, i.e., a thing of use cut off from the context of use. Indeed a thing of use can become cut off from the context of use, but then we are no longer viewing it in its equipmentality.) At the level of such circumspective dealings with equipment, where we take the hammer as something for nailing boards 
together, interpretation is carried on at the level of the "hermeneutic 'as'." At this level we articulate relations between things of use which have been disclosed in the understanding. And since the world is constituted by the structure of significance (this includes the "in order to," the "towards which," and the "for the sake of," which form a structural heirarchy) interpretation at the level of the hermeneutic 'as' articulates our understanding of the world into which we have been thrown. Here we can see Heidegger's fundamental departure from "the Greeks": Heidegger argues that at its most fundamental level, the hermeneutic level, logos is a ready-to-hand articulation and sharing of meaning or significance, while he argues that the Greeks implicitly conceived the logos as a presentat-hand succession of words. In Being and Time and The Basic Problems of Phenomenology Heidegger claims that this view of language is mistaken because it presupposes an agreement between representations in the mind and things outside the mind, an agreement which this view of language is powerless to explain. Heidegger seeks to dissolve the problem of correspondence by making the ontological distinction which he says was missed by the Greeks, namely the distinction between presence-at-hand and other modes of Being (specifical1y, Existence and readiness-to-hand): his appeal to a three-fold temporal structure of human Being and to an internally related, ready-to-hand totality of significations enables him to conceive Dasein and world as coextensive and to argue that the essence of assertion is discovery rather than the synthesis of nouns and verbs, though as we shall see interpretation on Heidegger's account always involves a kind of synthesis.

Interpretation has a circular structure insofar as all interpretation is guided by a three-fold forestructure: a discussion of the fore-structure at this point would take us too far afield of the issue under consideration, but we must note in passing that Dasein's interpretation is always guided by its current (and this means already prevailing) understanding of itself and its world. Dasein's interpretation is always guided by the way in which its possibilities have already been disclosed and articulated: Dasein is essentially ahead of itself (Cf. BT 191f). What this means concretely is that what we take some item of equipment as is guided by our prior understanding of things.

What must be noted here is that Heidegger discusses interpretation in terms of a projective disclosure of beings in their possibility. And to the extent that dealings with beings at the level of readiness-to-hand somehow disclose those beings, Heidegger is in Being and Time committing himself to the controversial view that circumspective dealings with equipment are somehow true. 
We have already seen that Heidegger situates asserting against the background of a broader notion of interpretation. And we have seen that at the most "primordial" level, interpretation involves the hermeneutic 'as', the 'as' of concernful involvement. On the other hand, assertion involves the apophantic 'as', an 'as' which is explicit rather than implicit; and that what is discussed in an assertion has been "dimmed down" means that the object of discourse has been cut off from reference relations in such a way that it has been isolated for inspection (BT 197). What is common to both levels of interpretation is that all interpretation involves a synthesis, which Heidegger discusses in terms of the quality of Beisammen ("together"); that all interpretation involves the 'as' structure; and that all interpretation operates within the circular structure of understanding. This account of interpretation might lead one to conclude that there are two discrete kinds of interpretation, one on the level of concernful dealings and the other on the level of pure theory; however, this is not the case. Heidegger suggests that there are many gradations between interpretation which is wrapped up in "concernful understanding" and the level of "theoretical assertion about something present-at-hand" (BT 200f). There are many statements about the world of concern which are not theoretical; for example, the statement "this hammer is too heavy" can occur only within the context of some project involving a hammerer who finds the hammer "too heavy."

In presenting the above anatomy of assertion, Heidegger says that any understanding of assertion as being essentially predication misses the genuine essence of assertion. Unless we view assertion as a way of Being-in-the-world (BT 260f) we are doomed to misunderstand the real essence of assertion, which is discovery. That is, assertion and circumspective interpretation share the common essence of discovery. The truth of assertion lies in its Being-uncovering (BT 261) and the truth of everyday dealings lies in their disclosive articulation of beings or possibilities. Assertions are true insofar as they discover beings just as they are ("so... . wie"). and Dasein's dealings are true insofar as they discover whatsoever (BT 263). If we wonder why the tradition has equated truth with assertion, Heidegger will tell us that that is the result of the Greeks' mistakenly conceiving the logos as present-at-hand: ". . . the methodological basis on which ancient ontology arose was not a primordial one. The logos gets experienced as something present-at-hand and Interpreted as such, while at the same time the entities which it points out have the meaning of presence-at-hand" (BT 203). And Heidegger says that this focus on presence caused the Greeks to miss other modes of Being, with the result that they and the rest 
of the tradition go astray in attempting to characterize human being and the world. The picture of "the Greeks," particularly of Aristotle, which emerges, is the following: they understood the logos as a presentat-hand succession of words, but they viewed all truth (in aisthesis and noesis as well as in assertion) in terms of discovery and covering up."

In discussing the "primordial notion of truth" in paragraph 44 of Being and Time, Heidegger says that Dasein is primarily true insofar as Dasein discovers, that beings are discovered in concern (Besorgen), and that truth is equivalent to discoveredness; and that is why I have suggested above that activities like hammering are "true" for Heidegger in Being and Time. There he calls Dasein's activity of discovering "primarily true" and the discoveredness of beings "true.in a second sense" (BT 263). Eurthermore, discovery and discoveredness of beings are grounded in the disclosedness of Dasein and world; that is, the discovery and articulation of beings or possibilities are grounded in the fact that Dasein exists as care, as always already in a world alongside beings. On this account, Dasein's disclosedness is "the most primordial phenomenon of truth. . . In so far as Dasein is its disclosedness essentially, and discloses and uncovers as something disclosed to this extent it is essentially 'true'. Dasein is 'in the truth'" (BT' 263).

In order to fill out this preliminary sketch of Heidegger's concept of truth in Being and Time, we need to look at a few remarks concerning authenticity. In paragraph 44 Heidegger refers to authentic disclosedness as "the phenomenon of the most primordial truth in the mode of authenticity" (BT 264). This "most authentic disclosedness" is "the truth of existence." I mention these remarks in order to raise a methodological question: If we are to pursue Heidegger's phenomenological project, then just what are "the things themselves". Which we seelr? Whatever they may be, one thing seems certain: the phenomenological investigator must be authentic in order to arrive at the phenomena: "Because Dasein has falling as its kind of Being, the way Dasein gets interpreted is for the most part inauthentically 'oriented' and does not reach the essence; for to Dasein the primordially appropriate ontological way of formulating questions remains foreign. But whenever we see something wrongly, some injunction as to the primordial 'idea' of the phenomenon is revealed along with it" (BT 326). Thus it would seem that a "primordial" characterization of the phenomena can come only in the "moment" (Augenblick) in which Dasein makes transparent to itself its own being as nullity or thrown projection, insofar as Dasein is essentially falling and is thus equiprimordially in the truth and untruth. 


\section{II. "Plato's Doctrine of Truth"}

In "Plato's Doctrine of Truth" Heidegger suggests that the concept of truth as aletheia underwent a transformation in Plato's subjection of aletheia as unconcealedness to the idea. According to Heidegger, aletheia or truth for the Greeks first meant "that which has been wrested from concealedness." 10 But in making the movement of paideia in the cave metaphor a movement toward the idea (and in particular toward the idea ton agathon or idea of the good). Plato turns around the granting relationship so that unconcealedness no longer grants correctness; rather, starting with Plato the idea ton agathon grants unconcealedness. And accordingly there is a shift in the locus of truth; as unconcealedness, truth is a. "fundamental characteristic of beings themselves," but as correctness truth becomes the "distinction of human relating to beings." 2 That is, in the shift to the idea truth is conceived not as "wresting beings from concealedness" but as orthotes or "correctness of viewing," 12 and assertion becomes the "place" of truth. Heidegger believes that this shift gives rise to the presupposition of a totality of relations between intellectus and res, a presupposition which overlooks the context of Being (Seinszusammenhang) which grounds this totality. A related conclusion which Heidegger draws concerning this shift is that it signals the start of metaphysical thinking, which thinks the cause (Ursache) of all being as to theion or the divine (das Gbttliche). The cave metaphor is supposed to show how man comes to think the essence of truth as "correctness of representing of all beings according to "ideas" and estimates everything real according to "values"."13 In contrast to this conception of truth, Heidegger enjoins us to think unconcealedness as "the originating essence of truth," and maintains that "[n]o attempt to ground the essence of unconcealedness in 'reason' [Vernünft], in 'spirit' [Geist], in 'thinking', in 'logos', [or] in some sort of 'subjectivity' can ever save the essence of unconcealedness." 14

III. Heidegger's Reversal in "The End of Philosophy and the Task of Thinking"

In "The End of Philosophy and the Task of Thinking," Heidegger takes back his claim in "Plato's Doctrine of Truth" that the notion of truth underwent a transformation in Plato. Here he says that ". . aletheia, unconcealment in the sense of the opening of presence, was originally experienced only as orthotes. as the correctness of representations and statements. But then the assertion about the essential transformation of truth, that is, from unconcealment to correctness, is also untenable." is It seems that Heidegger is 
brought to this shift by Paul Friedländer's argument, presented in a book on Plato which appeared over twenty years before Heidegger's "The End of Philosophy and the Task of Thinking," that both meanings of aletheia (unconcealment and correctness) were already current in the early Greek world. ' Friedländer shows that both Homer and Hesiod used the term in the sense of correctness, though he diverges from Heidegger's claim that aletheia. first meant only correctness by referring to passages in the Iliad where the term is used in the sense of unconcealment.

Heidegger concludes that it was a mistake to call aletheia in the sense of unconcealment truth: "To raise the question of aletheia, of unconcealment as such, is not the same as raising the question of truth. For this reason, it was inadequate and misleading to call aletheia in the sense of opening, truth."17. But this conclusion on Heidegger's part is not exactly.the conclusion which Friedländer draws. Friedländer argues that Heidegger was engaging in false etymology in "Plato's Doctrine of Truth" in using the "alpha privative" analysis to conclude that aletheia was.a term of negation and originally meant "wresting from concealedness." For Friedländer aletheia always meant primarily orthotes or correctness. But Friedländer's main point is not merely one about faulty etymology; rather, his central criticism is much closer to Heidegger's own rethinking of aletheia. Friedländer argues, as does Ernst Tugendhat, That Heidegger's equating of truth and unconcealment subjectivizes the concept of truth: Heidegger's unconcealedness "certainly ought to save the concept of truth from modern subjectivization. But unconcealedness itself leads to subjectivization. . . . For there are not concealedness and unconcealedness pure and simple: (un)concealedness is nothing unless (un)concealed for someone." "s But Heidegger seems less interested in avoiding a subjectivization of the concept of truth than in adequately characterizing the relation between truth and unconcealment. He is willing to grant that we have always used the term "truth" in the sense of correctness, but that does not in any way affect the claim that unconcealedness grounds or grants the possibility of truth as correctness. Already in Being and Time Heidegger conceived unconcealedness (if only in the guise of disclosedness) as grounding truth as correctness. It is for this reason that Heidegger in a footnote to "The End of Philosophy and the Task of Thinking" says that in "Plato's Doctrine of Truth" he strayed from the essential insight in Being and Time that it is inappropriate to translate aletheia as "truth." In the relevant passage in Being and Time. Heidegger says that the translation of the term aletheia as "truth" misses the prephilosophical meaning of the term for the Greeks. namely the meaning of the term as unconcealedness (BT) 
262). Thus the prevailing usage in the early Greek world is not the appropriate court of appeal for adjudicating the question concerning truth, for the issue under consideration is an ontological one, one concerning the grounding relation between two phenomena. Thus, with Heidegger, we should want to say that unconcealedness has always granted truth as correctness; on this account the Greeks explicitly understood truth as correctness but overlooked the condition of its possibility because of the self-concealing character of unconcealedness. This self-concealing character is the source of the Greeks' orientation on presence, but this does not mean that they had no understanding of unconcealment; already in Being and Time Heidegger says that the Greeks had a pre-phenomenological understanding of it, and he notes that this understanding shows itself in the thought of Heraclitus (BT 262). It seems that Heidegger himself fell prey to the self-concealing character of unconcealment in first attempting to equate aletheia and truth.

In pondering the implications of this mistake, we must do more than simply bear in mind that truth is really correctness and that unconcealedness really grants truth and then move on to more pressing matters. The implications of Heidegger's shift must be pursued along two lines which are intimately related. Here I will simply state them briefly and leave them for the reader's consideration. First, we must rethink Heidegger's view in Being and Time that Dasein's Being is "true" and that the concernful manipulation of things of use is also true: it seems wrong to call activities like hammering "true," and perhaps hybristic to call Dasein's finite disclosedness "primordially true." Surely Heidegger always wanted to relativize truth to human being, but Heidegger seems to have gone too far in Being and Time by making the clearing--the open space within which beings can come to presence--coincide with Dasein's disclosedness. So we must rethink the relation between unconcealment and disclosedness. Second, we must rethink the clearing itself as an "event". (Ereignis) which has a divine dimension and which thus is not limited to human disclosedness. But even the talk of gods in the later essays of Vorträge und Aufsätze, while marking a sharp departure from Heidegger's former conception of clearing as disclosedness, remains very obscure. If we take the so-called "later" Heidegger seriously, then the task of thinking lies precisely in bringing the clearing in the sense of Ereignis to language and preserving it; in so doing, we are to begin to understand the essence of humanity and its relation to Being. And this is a task which lies before us. 
'Martin' Heidegger, "The End of Philosophy and the Task of Thinking," On Time and Being, trans. Joan Stambaugh (New York: Harper Torchbooks, 1972) 70.

${ }^{2}$ Being and Time, trans. John Macquarrie and Edward Robinson (NeW York: Harper and Row, 1962) 62 (hereafter BT).

${ }^{3}$ Martin Heidegger, Logik: Die Frage nach der Wahrheit (Erankfurt-am-Main: Klostermann, 1976) 7 .

"Cf:, e.g., "Logos (Heraklit, Eragment 50)," "Moira (Parmenides, Fragment VIII, 34-41)," and "Aletheia (Heraklit, Eragment 16)," Vorträge und Aufsätze, 4th ed. (Pfullingen: Neske, 1978).

${ }^{5} \mathrm{Cf}$ Gelassenheit, 7 th ed. (Pfullingen: Neske, 1982) $12 f$.

\section{'Logik 142.}

'De Interpretatione, The Basic Works of Aristotle, ed. Richard McKeon (New York: Random House, 1941) 40(16a4-8).

-BT 203, Die Grundprobleme der Phănomenologie (Erankfurt-am-Main: klostermann, 1975) 294.

'Cf. Logik $162 \mathrm{f}$.

10"Platons Lehre von der Wahrheit," Wegmarken 2d ed. (Erankfurt-am-Main: Klostermann, 1978) 221 .

" "Platons Lehre von der Wahrheit" $228 \mathrm{f}$.

12 "Platons Lehre von der Wahrheit" 228.

23 "Platons Lehre von der Wahrheit" 235.

" "Platons Lehre von der Wahrheit" 235.

18 "The End of Philosophy" 70.

ic"Aletheia," Platon, 2d ed., 3 vols. (Berlin: de Gruyter, 1954) 1: $2 \overline{33-242}$.

17 "The End of Philosophy" 70.

"Cf. Der Wahrheitsbegriff bei Husserl und Heidegger (Berlin: de Gruyter, 1970), and "Heideggers Begriff der Wahrheit," Heidegger. Perspektiven zur Deutung seines Werks, ed. Otto Pöggeler (Köln/Berlin: Kiepenheuer and witsch, 1969) 286-297. 